\title{
Mikrostruktura i właściwości eksploatacyjne Inconelu 625 w postaci warstw natryskiwanych cieplnie
}

\author{
Microstructure and service properties of Inconel 625 \\ as a thermal spraying surface layers
}

\section{Streszczenie}

Badaniom poddano warstwę wierzchnia wytworzoną metodą natryskiwania łukowego. Materiał dodatkowy w postaci Inconelu 625 natryskiwano na podłoże ze stali 13CrMo4-5. Wytworzone warstwy natryskiwane poddano badaniom twardości, określono przyczepność do podłoża, porowatość warstw oraz chropowatość przed obróbką wykańczającą. Przedstawiono parametry wytwarzania warstw przeznaczonych do pracy w warunkach obciążenia.

\section{Abstract}

Surface layer create by arc spraying has been investigated. As an addition material Inconel 625 has been used and spray on low alloyed steel type $13 \mathrm{CrMo} 4-5$ as a base material. Created layer has been researched in the range of hardness, surface adhesion, porosity and surface roughness before postspray machining. Variables of layers to work in service conditions creating have been presented.

\section{Wstęp}

Nadstopy na osnowie niklu są materiałami wykazującymi dużą odporność na zużycie w trudnych warunkach eksploatacyjnych. Agresywne środowisko w postaci cieczy lub gazów wymaga zastosowania wieloskładnikowych stopów o właściwościach ukształtowanych poprzez zawartość wielu pierwiastków stopowych. Skład chemiczny stanowi kilkanaście pierwiastków o znaczeniu podstawowym i kilkanaście pierwiastków uzupełniających. Złożony skład chemiczny i właściwości poszczególnych pierwiastków klasyfikują nadstopy na osnowie niklu jako materiały trudno spawalne. Ponadto problematyczne staje się wykorzystanie nadstopów podczas spajania materiałów różnoimiennych w procesie napawania. Materiały stanowiące podłoże często wymagają zabiegów dodatkowych przed spawaniem oraz muszą wykazywać spawalność z wybranym nadstopem jako materiałem dodatkowym. Podjęto próbę zmiany właściwości warstwy wierzchniej za pomocą natryskiwania łukowego. Jako materiał podłoża

Dr inż. Artur Wypych - Politechnika Poznańska. wykorzystano stal niskostopową 13CrMo4-5. Materiał ten o składzie chemicznym (\%): C - 0,16; $\mathrm{Mn}-0,64$; $\mathrm{Si}-0,19 ; \mathrm{P}-0,012 ; \mathrm{S}-0,015 ; \mathrm{Cr}-0,94 ; \mathrm{Mo}-0,47$; $\mathrm{Cu}-0,19 ; \mathrm{Al}-0,019$ charakteryzuje się dobrą plastycznością na zimno i na gorąco, jest łatwo obrabialny mechanicznie, może być stosowany $w$ temperaturze do $550^{\circ} \mathrm{C}$. Stal $13 \mathrm{CrMo} 4-5 \mathrm{w}$ postaci blach, odkuwek czy prętów jest stosowana $w$ przemyśle energetycznym i chemicznym.

Materiału dodatkowego w postaci Inconelu 625 użyto w procesie natryskiwania łukowego. Spośród nadstopów na osnowie niklu, Inconel 625 o składzie chemicznym (\%) C-0,02; $\mathrm{Mn}-0,2 ; \mathrm{Si}-0,2 ; \mathrm{Cr}-22 ; \mathrm{Ni}$ - osnowa; $\mathrm{Mo}-9 ; \mathrm{Nb}-3,3 ; \mathrm{Fe}-1$ wykazuje bardzo dobrą

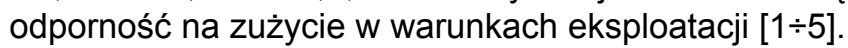
Dobra odporność korozyjna Inconelu 625 może być znacznie zredukowana przez udział materiału podłoża w warstwie wierzchniej, lecz wymieszanie się nadstopu z pierwiastkami pochodzącymi z podłoża, charakterystyczne dla napawania, nie występuje podczas natryskiwania łukowego. Dzięki temu wytworzona warstwa wierzchnia ma założone właściwości w odległości już kilku mikrometrów od linii osadzenia, z jednoczesnym brakiem negatywnego oddziaływania pierwiastków pochodzących z podłoża [6]. Ponadto 
niskotemperaturowe oddziaływanie materiału dodatkowego na podłoże jest korzystne dla materiałów wymagających stosowania dodatkowych zabiegów wstępnych. Parametry natryskiwania powinny zostać tak dobrane, aby temperatura podłoża nie przekroczyła $160^{\circ} \mathrm{C}$, wówczas nie występuje strefa wpływu ciepła charakterystyczna dla procesów napawania.

\section{Opis eksperymentu}

Przygotowanie materiału podłoża przed natryskiwaniem polegało na oczyszczeniu i odtłuszczeniu oraz rozwinięciu powierzchni w procesie obróbki strumieniowo-ściernej ziarnem korundowym o średnicy ziaren $0,3 \div 0,5 \mathrm{~mm}$, ciśnienie powietrza nadmuchującego ścierniwo wynosiło 4,5 bar. W związku z tym, że po obróbce ściernej ok. 1\% korundu zagnieżdża się w obrabianym materiale, konieczne jest ponowne oczyszczenie powierzchni w celu usunięcia pozostałych ziaren korundu. Obróbkę strumieniowo-ścierną przeprowadza się bezpośrednio przed natryskiwaniem, aby czas oddziaływania z otoczeniem był jak najkrótszy.

Zastosowano Inconel $625 \mathrm{w}$ postaci drutu proszkowego o średnicy $1,6 \mathrm{~mm}$. Pozostałe parametry natryskiwania przedstawiono w tablicy.

Badanie twardości wykonano na przekrojach poprzecznych próbek metodą Vickersa z zastosowaniem obciążenia wgłębnika wynoszącym 0,3 kg. Rozkład twardości w warstwie natryskiwanej i w materiale podłoża zbadano w kierunku oddalania się od linii osadzenia oznaczonej w początku układu współrzędnych (rys. 1). W wyniku braku wymieszania materiałów podczas natryskiwania, twardość wytworzonej warstwy nie zmienia się w funkcji odległości od podłoża. Podczas natryskiwania temperatura materiału podłoża nie przekroczyła $160^{\circ} \mathrm{C}$ i nie utworzyła się strefa wpływu ciepła charakterystyczna dla procesów napawania. Wystąpił niewielki wzrost twardości materiału podłoża o zasięgu do $15 \mu \mathrm{m}$ od linii osadzenia w wyniku naprężeń i ciepła przekazanego przez natryskiwane drobiny materiału dodatkowego (rys. 1 i 3). Poza tym obszarem materiał podłoża ma postać niezmienionego strukturalnie rdzenia.

Mikrostruktura warstwy natryskiwanej składa się z odkształconych plastycznie drobin z umieszczonymi między nimi pasmami tlenkowymi, niestopionymi drobinami i porami (rys. 4). Mikrostruktura stali nie ulega przemianom cieplnym na skutek oddziaływania temperatury z zakresu poniżej występowania SWC w stali. Materiał podłoża w całej objętości ma strukturę ferrytyczno-perlityczną niewrażliwą na oddziaływanie temperatury o wartości mniejszej niż $160^{\circ} \mathrm{C}$.

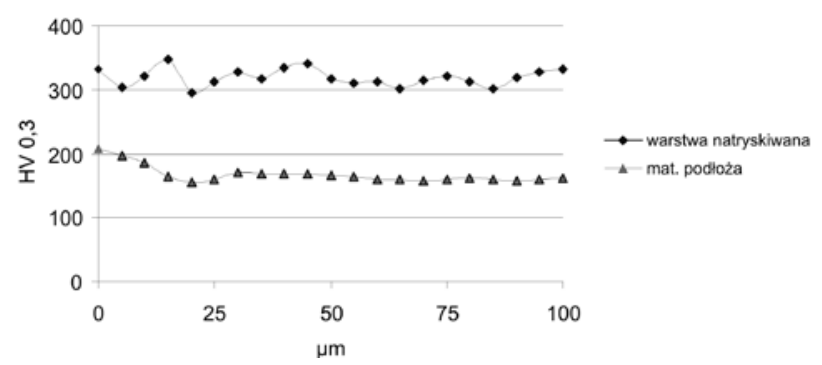

Rys. 1. Rozkład twardości w warstwie natryskiwanej i w materiale podłoża

Fig. 1. Hardness distribution in the spraying layers and substrate

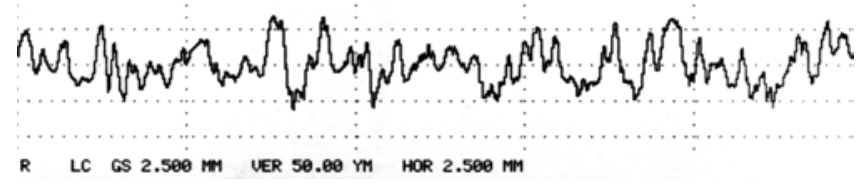

Rys. 2. Wyniki pomiarów chropowatości warstwy natryskiwanej; wartości parametrów $R_{z}=112,1$ i $R_{a}=21,6$

Fig. 2. Spraying layer surface roughness measurements results, the value of parameters $R_{z}=112,1$ and $R_{a}=21,6$

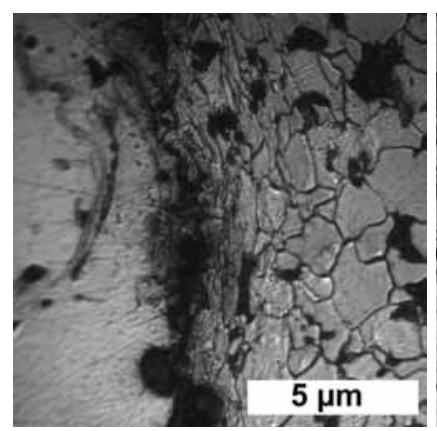

Rys. 3. Linia osadzenia i odkształceń powstałych w materiale podłoża; warstwa natryskiwana od lewej; podłoże od prawej

Fig. 3. Deposition line and deformations in the substrate, arc sprayed layer on the left, substrate on the right

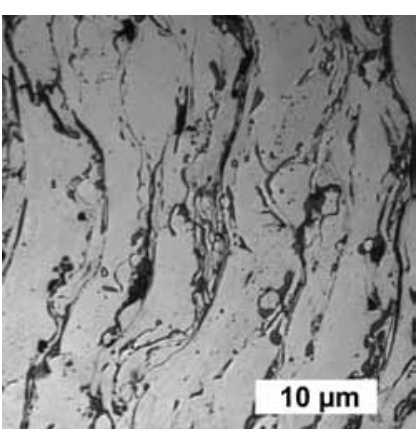

Rys. 4. Struktura warstwy natryskiwanej

Fig. 4. Structure of arc sprayed layer
Wytrzymałość powłoki i przyczepność do podłoża określono podczas próby odrywania powierzchni czołowych. Wykonano serię dziesięciu prób przyczepności warstwy. Różnice wartości siły zrywającej są niewielkie i średnia wartość przyczepności wynosi 26,4 MPa, przy czym najmniejsza siła zrywająca ma wartość 24,3 MPa, a największa siła zrywająca wynosi 28,6 MPa. Wartości te wskazują na dobrą przyczepność warstwy natryskiwanej do podłoża.

O trwałości czasowej w warunkach obciążenia warstwy natryskiwanej w dużym stopniu decyduje jej

Tablica. Parametry natryskiwania łukowego

Table. Parameters of arc spraying

\begin{tabular}{|c|c|c|c|c|c|}
\hline $\begin{array}{c}\text { Natężenie } \\
\text { prądu, A }\end{array}$ & $\begin{array}{c}\text { Napięcie } \\
\text { łuku, V }\end{array}$ & $\begin{array}{c}\text { Ciśnienie } \\
\text { powietrza, bar }\end{array}$ & $\begin{array}{c}\text { Prędkość liniowa } \\
\text { natryskiwania, cm/s }\end{array}$ & $\begin{array}{c}\text { Prędkość podawa- } \\
\text { nia drutu, m/min }\end{array}$ & $\begin{array}{c}\text { Odległość } \\
\text { od podłoża, mm }\end{array}$ \\
\hline 250 & 30 & 4 & 45 & 15 \\
\hline
\end{tabular}


chropowatość. W strumieniu mediów zawierających składniki wywołujące korozję, wystające z powierzchni drobiny powodują zwiększenie zużycia wskutek zwiększonej szybkości przepływu korozyjnych mediów i efektu wymywania.

Badanie polegało na skanowaniu głowicą pomiarową pięciu równoległych ścieżek, odległych od siebie o $1 \mathrm{~mm}$. Długość jednej ścieżki wynosiła $175 \mathrm{~mm}$, natomiast długość pomiarowa na tym odcinku to $125 \mathrm{~mm}$. Uzyskane wyniki chropowatości są dość duże, lecz jest to cecha warstw natryskiwanych łukowo niepoddanych obróbce mechanicznej. Znaczne zmniejszenie chropowatości jest możliwe dzięki zastosowaniu obróbki wykańczającej w postaci skrawania lub szlifowania. Obróbka skrawaniem jest nieco utrudniona ze względu na znaczną ciągliwość Inconelu 625 i wymaga stosowania specjalnych narzędzi skrawających. Za pomocą szlifowania końcowego możliwe jest zmniejszenie chropowatości o ponad 90\%. Z punktu widzenia właściwości eksploatacyjnych najbardziej istotne są parametry $R_{a}$ i $R_{z}$ [7]. Parametr $R_{a}$ ma postać średniej arytmetycznej bezwzględnych rzędnych profilu wewnątrz odcinka pomiarowego i obliczany jest jako całka pola pod wykresem, parametr $\mathrm{R}_{\mathrm{z}}$ jest wysokością chropowatości wg 10 punktów i oblicza się go jako średnią odległość 5 najwyżej położonych wierzchołków od 5 najniżej położonych wierzchołków (rys. 2).

Warstwy natryskiwane łukowo z Inconelu 625 poddano badaniu porowatości. Przy użyciu metody graficznej pomiaru uzyskano wynik na poziomie 9,8\%. Dla materiałów tego typu wykazujących dużą lepkość i przy grubości warstwy powyżej $1 \mathrm{~mm}$, wynik ten jest w zupełności zadowalający i nie wpłynie na obniżenie właściwości użytkowych warstwy (rys. 4).

\section{Wnioski}

Uzyskana twardość warstwy natryskiwanej jest nieduża i zawiera się w przedziale $300 \div 350$ HV0,3, dzięki temu szybko i łatwo można przeprowadzać mechaniczną obróbkę wykańczającą za pomocą szlifowania. Biorąc pod uwagę dużą gęstopłynność Inconelu 625 uzyskano porowatość na poziomie $10 \%$, co przy grubości warstwy powyżej $1 \mathrm{~mm}$ nie wpływa negatywnie na jej właściwości eksploatacyjne. Przyczepność warstwy wynosi 26,4 MPa i jest wystarczająca do zastosowań w warunkach obciążenia, ponadto warstwa jest spójna - nie uległa rozwarstwieniu w próbie rozciągania. Podczas natryskiwania łukowego Inconelu 625 na stal $13 \mathrm{CrMo} 4-$ 5 najwyższa temperatura podłoża nie przekracza $160^{\circ} \mathrm{C}$, a naprężenia powstałe w wyniku odkształceń w strukturze podłoża mają zasięg do $15 \mu \mathrm{m}$. Przy założonych parametrach natryskiwania łukowego możliwe jest wytworzenie warstwy z Inconelu 625 jako warstwy wierzchniej przeznaczonej do użytku w warunkach obciążenia.

\section{Literatura}

[1] Nowacki J., Wypych A., Wpływ technologii napawania na jakość napoin, Mat. Konf. XXXIII Szkoły Inżynierii Materiałowej Kraków - Ustroń 4-7 X 2005, s. 261-266.

[2] Nowacki J., Wypych A., Zrobotyzowane napawanie stali niestopowych nadstopami niklu, Biuletyn Instytutu Spawalnictwa w Gliwicach, 5/2005, r. 49, s. 58-65.

[3] Nowacki J., Wypych A., Problemy zużycia i modyfikacji warstwy wierzchniej głowic silników okrętowych, Przegląd Spawalnictwa $7 / 2010$, s. 2-7.

[4] Nowacki J., Wypych A., Napawanie w regeneracji głowic cylindrowych silników okrętowych, Przegląd Spawalnictwa - art. przyjęty do druku.
[5] Formanek, B.; Szymanski, K.; Szczucka-Lasota, B.; Wlodarczyk, A., New generation of protective coatings intended for the power industry Journal of Materials Processing Tech. Volume: 164-165, Complete, May 15, 2005, s. 850-855.

[6] Thivillon, L.; Bertrand, Ph.; Laget, B.; Smurov, I., Potential of direct metal deposition technology for manufacturing thick functionally graded coatings and parts for reactors components, Journal of Nuclear Materials Volume: 385 , Issue: 2 , March 31, 2009, s. 236-241.

[7] Zhong, Z.W.; Peng, Z.F.; Liu, N., Surface roughness characterization of thermally sprayed and precision machined WCCo and Alloy- 625 coatings Materials Characterization Volume: 58, Issue: 10, October, 2007, s. 997-1005.

\section{W następnym numerze}

Paweł Cegielski, Andrzej Kolasa, Krzysztof Skrzyniecki, Paweł Kołodziejczak

Komputerowy system do badań właściwości statycznych i dynamicznych źródeł energii elektrycznej do spawania łukowego

Krzysztof Pańcikiewicz, Sławomir Kwiecień, Edmund Tasak

Właściwości złączy spawanych ze stali 7CrMoVTiB10-10 (T24) po obróbce cieplnej

Aneta Ziewiec, Paweł Zbroja, Edmund Tasak

Skłonność do pęknięć gorących, austenitycznej stali Super 304H przeznaczonej do pracy w podwyższonej temperaturze 